\title{
The influence of freshwater discharge on the distribution of zooplankton in the southern Kara Sea
}

Accepted: 17 December 2001 / Published online: 14 March 2002 (C) Springer-Verlag 2002 gions are of great importance for the formation of water masses and sea ice (Lisitsyn and Vinogradov 1995), and additionally are of great significance for zooplankton with respect to growth and reproduction (Kosobokova and Hirche 2000).

The Kara Sea covers an area of $883,000 \mathrm{~km}^{2}$ and is one of the very shallow Siberian shelf seas, which in its central part hardly exceeds a depth of $40-50 \mathrm{~m}$. It is separated from the influence of the Barents Sea by Novaya Semlya to the west and by the Vilkitsky Archipelago from the Laptev Sea to the east (Cherkis et al. 1991), while to the north it opens into the Arctic Ocean (Fig. 1).

The hydrographic characteristics of the Kara Sea are intermediate between those of the Laptev and Barents Seas. While the latter is referred to as rather temperate due to the influence of the Transatlantic Current, the Laptev Sea is clearly high-arctic (Volkov et al. 1997; Løset et al. 1999). The biogeographical data available (Vinogradov et al. 1995b and references therein) all support the intermediate status of the Kara Sea.

In its southern part, the Kara Sea is strongly influenced by the immense freshwater discharge of the two river systems, $\mathrm{Ob}$ and Yenisej (Gordeev et al. 1996), which provide one-third of the total fresh water entering the Arctic Ocean and about $55 \%\left(1,290 \mathrm{~km}^{3}\right.$ year $\left.{ }^{-1}\right)$ of the total continental river run-off to the entire Siberian Arctic (e.g. Pavlov and Pfirman 1995). The two rivers contribute about $80 \%$ of the run-off to the Kara Sea. While the $\mathrm{Ob}$ has the largest length and drainage area, the Yenisej has, with $620 \mathrm{~km}^{3}$ year ${ }^{-1}$, the greatest discharge volume of all the Siberian rivers (Telang et al. 1991; Gordeev et al. 1996). The river run-off shows a strong seasonal and interannual variability, with a maximum in June when the coastal zone is still icecovered (Gordeev et al. 1996).

Little is known of the influence of the large freshwater discharge on the pelagic fauna of the Kara Sea. The freshwater signal is assumed to be the main structuring factor for the marine fauna in the estuaries through

rapid changes in salinity and temperature. Thus, during
I. Fetzer $(\bowtie) \cdot$ H.J. Hirche

Alfred-Wegener Institute for Polar- and Marine Research,

Columbusstrasse 1, 27568 Bremerhaven, Germany

Fax: + 49-471-48311149

E.G. Kolosova

Faculty of Biology, Moscow State University,

Vorobievy Gory, 119899 Moscow, Russia 


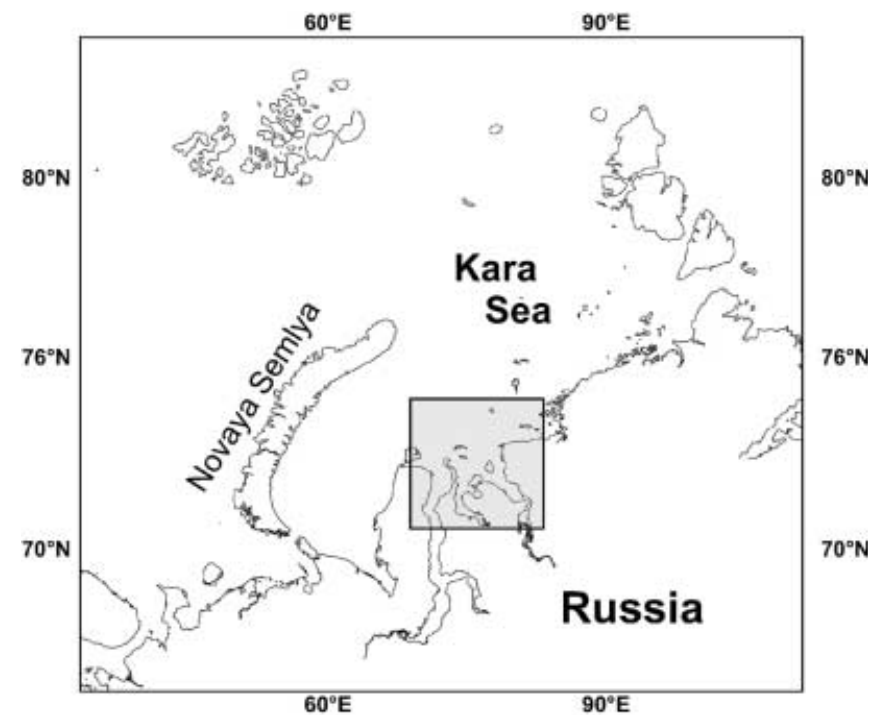

Fig. 1. Sampling area

the Russian Mendeleev Expedition in August/October 1993 to the southern part of the Kara Sea up to $76^{\circ} \mathrm{N}$, three types of zooplankton communities were identified (Vinogradov et al. 1995b): (1) one adapted to the eddy of the southwestern part of the sea, which was dominated by copepodite stage V (CV) Calanus finmarchicus s.l. (57\% biomass); (2) a community of the coastal areas of the Yamal Peninsula and Baidara Bay consisting of Chaetognatha and small plankters such as Oithona similis, Pseudocalanus minutus and P. acuspes (20-77\% biomass); and (3) one associated with the detritus-rich brackish waters in the eastern regions. There the biomass was relatively high and consisted $>50 \%$ of C. finmarchicus. The highest concentrations were found in the bottom layers and in the salinity mixing front. The communities within the estuaries of $\mathrm{Ob}$ and Yenisej showed strong differences, with $\mathrm{Ob}$ Bay much richer both in abundance and species number (Vinogradov et al. 1995a).

The rivers also affect food distribution. According to observations during the Mendeleev Expedition (Lisitsyn and Vinogradov 1995; Vinogradov et al. 1995b), and work conducted in the inner estuaries (Vinogradov et al. 1995a), it seems that the central Kara Sea is characterised by a strong oligotrophy (Lisitsyn et al. 1995). The rivers, in contrast, supply the estuaries with nutrients (Telang et al. 1991; Lisitsyn 1995) that may enhance primary production (Verdernikov et al. 1995). Furthermore, the input of high loads of organic material should promote or constrain the presence of some pelagic species (Makkaveev 1995). Thus it is assumed that some species can directly utilise river-borne detritus as a food source (Roman 1984; Tackx et al. 1995), although Vinogradov et al. (1995a) suggested that the bulk of the detritus in the Kara Sea sinks to the bottom and is not used by zooplankton. The large amount of bacteria and protozoans, which thrive on the detritus (Mitskevich and Namsaraev 1995), may serve as an alternative food source for zooplankton.

The aim of the present study is to analyse characteristics of the mesoplankton distribution in the $\mathrm{Ob}$ and Yenisej estuaries in relation to hydrographic features in 1997 and 1999. The data were collected during two expeditions of RV "Akademik Boris Petrov" as part of the joint Russian-German project "Siberian River Run-off" (SIRRO), which focused on the transformation processes of organic matter in the Siberian Seas.

\section{Materials and methods}

The data were collected during two cruises of R/V "Akademik Boris Petrov" from 13 to 25 September 1997, and from 26 August to 9 September 1999 , between 72 and $74^{\circ} \mathrm{N}$ and 72 and $83^{\circ} \mathrm{E}$. During the expeditions, 20 (1997) and 24 (1999) stations were visited, respectively. Zooplankton samples were collected with a Nansen closing net (vertical net, $0.442 \mathrm{~m}^{2}$ catching area, $150 \mu \mathrm{m}$ mesh size; $0.5 \mathrm{~m} / \mathrm{s}$ hauling speed). Four net samples were taken at each station: two below and two above the halocline, which was determined from a CTD profile before sampling. At shallow stations $(<10 \mathrm{~m}$ depth), the Nansen net frame was mounted with a non-closing, short net of $1 \mathrm{~m}$ length. Since the short net could not be closed, only two samples of the whole water column were landed per station. The samples were preserved in $4 \%$ borax-buffered formaline. All specimens were counted and measured under a stereomicroscope and identified to species level if possible. Copepodite stages of calanoid copepods were also identified and counted. Prosome length was used to distinguish copepodites and adult females of the two closely related copepods $C$. finmarchicus and C. glacialis, according to Hirche et al. (1994). Prosome length was measured from the tip of the cephalosome to the distal lateral end of the last thoracic segment.

Overall distribution and community analysis [hierarchical, agglomerative cluster analysis and non-metrical Multi-Dimensional Scaling (MDS)] in relation to abiotic data was performed using the PRIMER package (Clarke 1993; Clarke and Warwick 1994). To reduce the emphasis of abundant species, data were double squareroot transformed. Preliminary clustering analysis showed that samples of the two depth layers were more similar to each other than to all other samples, e.g. resulted in paired clusters, so the data of the net hauls were pooled in further analyses. In order to identify the characteristic species assemblages responsible for each cluster, the number of species was first reduced, retaining only those that accounted for $>4 \%$ of the total abundance at any one site, and then the single stations were grouped according to the results of the cluster analysis. Afterwards the species were sorted according to occurrence and abundance (also referred to as Shade matrix). The species principally responsible for the sample grouping in the cluster analysis (e.g. the one with the highest abundances) were then highlighted. This simple but informative approach was chosen to concentrate on the species similarities (Clarke and Warwick 1994).

\section{Results}

Sea ice and river discharge

The Kara Sea is usually covered by ice for about 9 months of the year (Blanchet et al. 1995). Ice formation starts at the end of September or beginning of October; the break-up begins in early to late June (Mironov et al. 1994). River run-off exhibits a large seasonal 
variation with most of the discharge occurring during June to September (Pavlov and Pfirman 1995). During our expeditions, the southern Kara Sea was completely ice-free and the hydrography was strongly influenced by the two river systems.

1997

\section{Hydrography}

In 1997, the depth range of the 20 stations varied between $40 \mathrm{~m}$ off the Taymyr Peninsula (st. 21) and $10 \mathrm{~m}$ within the Yenisej Estuary (st. 32; Table 1). The hydrography was described in detail by Churun and Ivanov (1998). Salinity and temperature distribution at $2 \mathrm{~m}$ depth, together with north to south transects in the two rivers, are presented in Fig. 2 (Fig. 3 gives the salinity and temperature distribution in 1999). Both salinity and temperature showed a sharp gradient from the innermost parts of the estuaries to the outer parts, with a strong gradient in an east to west direction in the $\mathrm{Ob}$ and in a south to north direction in the Yenisej. Salinity in the upper layer increased from 1 in the Yenisej and 4 in the $\mathrm{Ob}$ to $21 \mathrm{psu}$ at the outermost stations, while temperature decreased from $8^{\circ} \mathrm{C}$ in the Yenisej and from

Table 1. Station data on the expeditions "Boris Petrov" 1997 and 1999. Stations marked with * were excluded in transects (see text for further explanations) (\# indicates no lower layer available or too shallow)

\begin{tabular}{|c|c|c|c|c|c|c|c|c|c|c|}
\hline & Station & Date & $\begin{array}{l}\text { Latitude } \\
\text { (N) }\end{array}$ & $\begin{array}{l}\text { Longitude } \\
\text { (E) }\end{array}$ & $\begin{array}{l}\text { Depth } \\
\text { (m) }\end{array}$ & $\begin{array}{l}\text { Salinity } \\
\text { surface/ } \\
\text { bottom }\end{array}$ & $\begin{array}{l}\text { Temp. }\left({ }^{\circ} \mathrm{C}\right) \\
\text { surface/ } \\
\text { bottom }\end{array}$ & $\begin{array}{l}\text { No. of } \\
\text { species } \\
(N)\end{array}$ & $\begin{array}{l}\text { Abundance } \\
\text { upper layer } \\
\text { (ind. } \mathrm{m}^{-2} \text { ) }\end{array}$ & $\begin{array}{l}\text { Abundance } \\
\text { lower layer } \\
\text { (ind. } \mathrm{m}^{-2} \text { ) }\end{array}$ \\
\hline \multicolumn{11}{|l|}{1997} \\
\hline \multirow{4}{*}{$\mathrm{Ob}$ transect } & 47 & 22 Sep & $72^{\circ} 35^{\prime}$ & $73^{\circ} 44^{\prime}$ & 18 & $19.3 / 29.5$ & $4.1 / 0.5$ & 23 & 2943 & 4639 \\
\hline & 48 & 22 Sep & $72^{\circ} 57^{\prime}$ & $73^{\circ} 00^{\prime}$ & 28 & $13.9 / 31.1$ & $4.5 /-1.3$ & 30 & 342 & 1773 \\
\hline & 49 & 23 Sep & $73^{\circ} 12^{\prime}$ & $72^{\circ} 53^{\prime}$ & 29 & $16.6 / 31.5$ & $4.3 /-1.5$ & 30 & 302 & 599 \\
\hline & 52 & 24 Sep & $74^{\circ} 00^{\prime}$ & $72^{\circ} 39^{\prime}$ & 29 & $18.1 / 32.0$ & $4.2 /-0.3$ & 27 & 651 & 717 \\
\hline \multirow[t]{6}{*}{ Yensisej transect } & 32 & 19 Sep & $72^{\circ} 05^{\prime}$ & $81^{\circ} 28^{\prime}$ & 10 & $1.0 / 15.0$ & $8.3 / 5.8$ & 10 & 241 & \# \\
\hline & 30 & $18 \mathrm{Sep}$ & $72^{\circ} 30^{\prime}$ & $80^{\circ} 20^{\prime}$ & 13 & $4.3 / 13.1$ & $7.2 / 5.0$ & 14 & 285 & \# \\
\hline & 27 & $18 \mathrm{Sep}$ & $72^{\circ} 53^{\prime}$ & $80^{\circ} 05^{\prime}$ & 19 & $4.8 / 30.3$ & $6.5 /-0.1$ & 24 & 749 & 985 \\
\hline & 38 & $20 \mathrm{Sep}$ & $73^{\circ} 12^{\prime}$ & $80^{\circ} 00^{\prime}$ & 31 & $7.2 / 31.3$ & $6.4 /-0.9$ & 23 & 552 & 558 \\
\hline & 24 & 17 Sep & $73^{\circ} 32^{\prime}$ & $79^{\circ} 55^{\prime}$ & 39 & $11.3 / 31.4$ & $6.0 /-1.7$ & 27 & 588 & 2128 \\
\hline & 21 & 17 Sep & $74^{\circ} 00^{\prime}$ & $81^{\circ} 00^{\prime}$ & 40 & $14.8 / 32.0$ & $5.9 /-1.8$ & 30 & 930 & 1717 \\
\hline \multirow{3}{*}{ Middle transect } & 46 & 21 Sep & $73^{\circ} 59^{\prime}$ & $77^{\circ} 12^{\prime}$ & 27 & $12.4 / 32.0$ & $6.4 /-1.4$ & 25 & 274 & 820 \\
\hline & $42 *$ & 20 Sep & $73^{\circ} 53^{\prime}$ & $81^{\circ} 40^{\prime}$ & 30 & $15.1 / 32.0$ & $5.9 /-1.8$ & 29 & 221 & 1983 \\
\hline & $43^{*}$ & 20 Sep & $73^{\circ} 42^{\prime}$ & $82^{\circ} 48^{\prime}$ & 31 & $11.2 / 21.4$ & $6.0 / 0.5$ & 27 & 523 & 279 \\
\hline \multicolumn{11}{|l|}{1999} \\
\hline \multirow[t]{7}{*}{ Ob transect } & 19 & 1 Sep & $72^{\circ} 11^{\prime}$ & $74^{\circ} 11^{\prime}$ & 14 & $1.9 / 11.0$ & $2.5 / 0.6$ & 15 & 1649 & \# \\
\hline & 18 & 1 Sep & $72^{\circ} 19^{\prime}$ & $74^{\circ} 00^{\prime}$ & 15 & $1.7 / 26.0$ & $4.0 /-0.4$ & 29 & 760 & 690 \\
\hline & 20 & 2 Sep & $72^{\circ} 30^{\prime}$ & $74^{\circ} 43^{\prime}$ & 16 & $2.8 / 27.0$ & $3.9 / 0.1$ & 29 & 1017 & \# \\
\hline & 17 & $31 \mathrm{Aug}$ & $72^{\circ} 51^{\prime}$ & $73^{\circ} 56^{\prime}$ & 19 & $5.3 / 29.9$ & $3.6 /-1.2$ & 32 & 1444 & 2270 \\
\hline & 21 & $3 \mathrm{Sep}$ & $73^{\circ} 14^{\prime}$ & $74^{\circ} 02^{\prime}$ & 16 & $7.0 / 23.5$ & $3.5 /-1.4$ & 20 & 550 & 2314 \\
\hline & 25 & 4 Sep & $74^{\circ} 00^{\prime}$ & $73^{\circ} 59^{\prime}$ & 26 & $8.9 / 32.0$ & $3.4 / 0.1$ & 26 & 277 & 575 \\
\hline & 37 & 8 Sep & $74^{\circ} 18^{\prime}$ & $74^{\circ} 20^{\prime}$ & 30 & $9.8 / 32.3$ & $2.9 /-1$ & 27 & 416 & 665 \\
\hline Yenisej transect & 6 & 28 Aug & $72^{\circ} 17^{\prime}$ & $80^{\circ} 01^{\prime}$ & 7 & $2.6 / 3.0$ & $6.6 / 6.6$ & 16 & 1386 & \# \\
\hline \multirow{7}{*}{ Middle transect } & 38 & 8 Sep & $74^{\circ} 15^{\prime}$ & $75^{\circ} 36^{\prime}$ & 30 & $11.1 / 32.2$ & $3.1 /-0.3$ & 24 & 560 & 509 \\
\hline & 39 & 9 Sep & $74^{\circ} 17^{\prime}$ & $76^{\circ} 49^{\prime}$ & 38 & $10.6 / 33.0$ & $2.9 /-0.8$ & 22 & 74 & 523 \\
\hline & 2 & 26 Aug & $74^{\circ} 30^{\prime}$ & $75^{\circ} 55^{\prime}$ & 30 & $5.5 / 29.3$ & $4.1 /-1.9$ & 25 & 2151 & 545 \\
\hline & $1 *$ & $26 \mathrm{Aug}$ & $73^{\circ} 59^{\prime}$ & $74^{\circ} 30^{\prime}$ & 27 & $6.0 / 31.0$ & $3.9 /-1.8$ & 31 & 2747 & 479 \\
\hline & $3 *$ & $27 \mathrm{Aug}$ & $73^{\circ} 48^{\prime}$ & $79^{\circ} 59^{\prime}$ & 32 & $5.9 / 30.6$ & $3.7 /-1.7$ & 23 & 1703 & 604 \\
\hline & $29^{*}$ & $5 \mathrm{Sep}$ & $73^{\circ} 05^{\prime}$ & $78^{\circ} 30^{\prime}$ & 17 & $8.7 / 26.9$ & $3.4 /-1.0$ & 18 & 454 & 4000 \\
\hline & $30 *$ & 6 Sep & $72^{\circ} 27^{\prime}$ & $79^{\circ} 17^{\prime}$ & 14 & $5.3 / 13.0$ & $5.5 / 3.9$ & 12 & 937 & \# \\
\hline
\end{tabular}


Fig. 2. 1997: salinity and temperature at $2 \mathrm{~m}$ and along the 2 transects based on 59 CTD stations. Station numbers indicate biological stations. Boxes show stations included in hydrographic transects

Fig. 3. 1999: salinity and temperature at $2 \mathrm{~m}$ and along the 2 transects based on 37 CTD stations. Station numbers indicate biological stations. Boxes show stations included in hydrographic transects
1997 Salinity $(2 \mathrm{~m})$

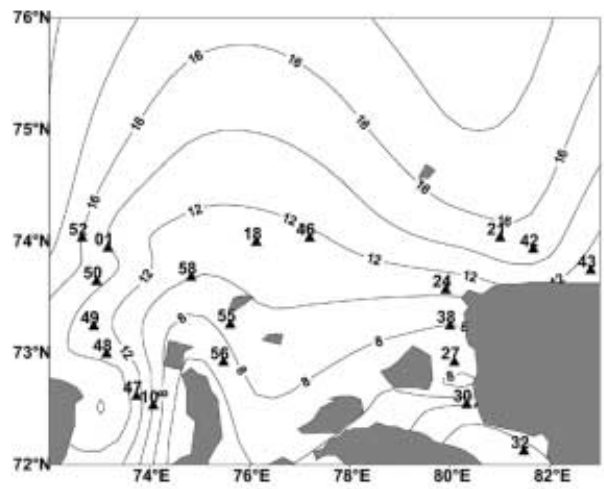

Temperature $(2 \mathrm{~m})$

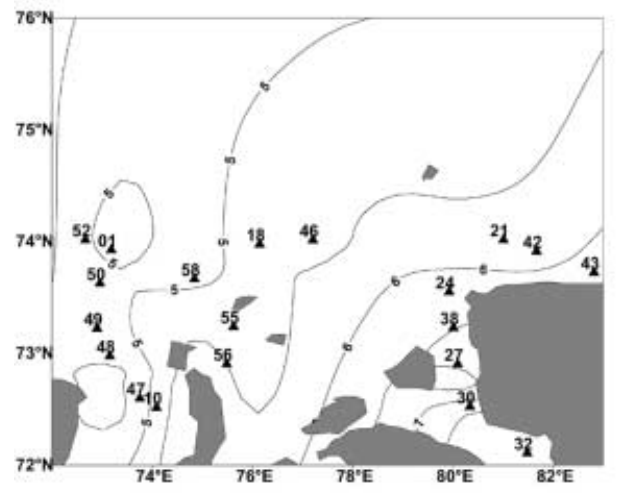

1999 Salinity $(2 \mathrm{~m})$

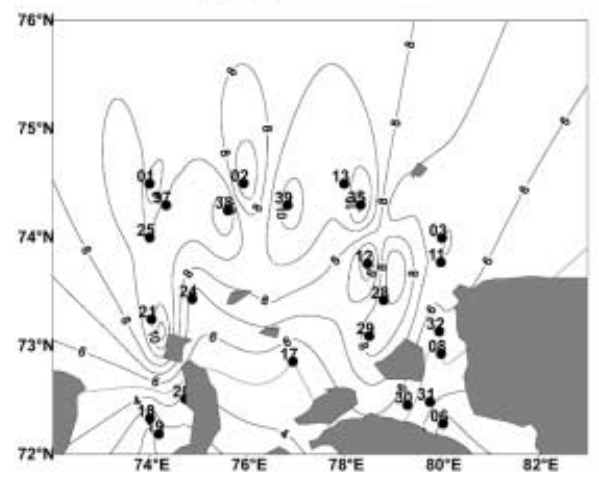

Temperature $(2 \mathrm{~m})$

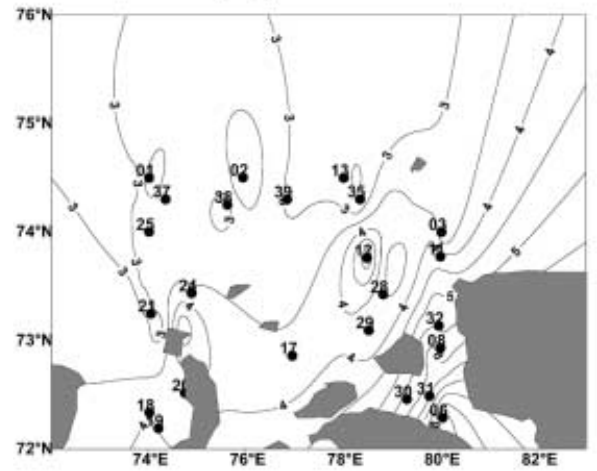

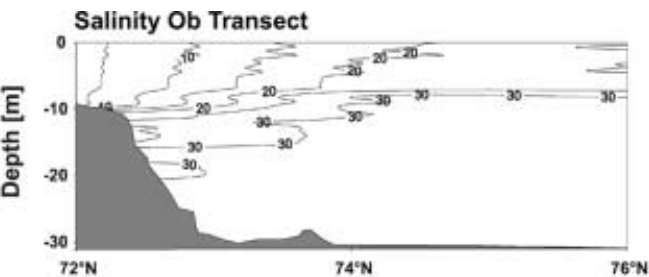

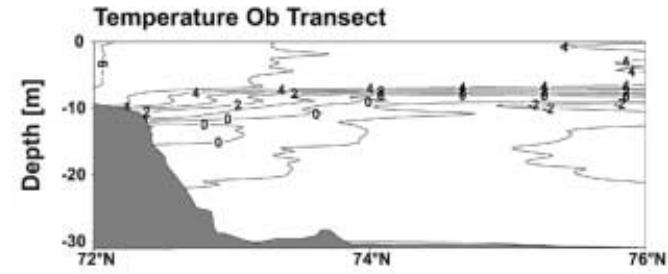

Salinity Yenisej Transect
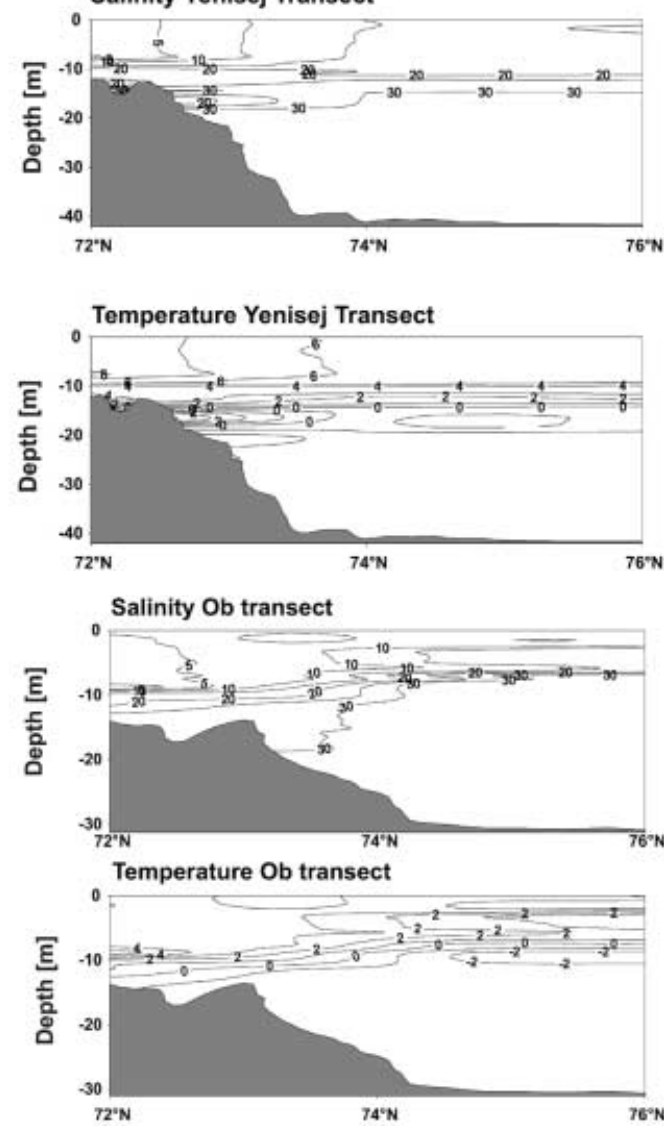

Salinity Yenisej transect
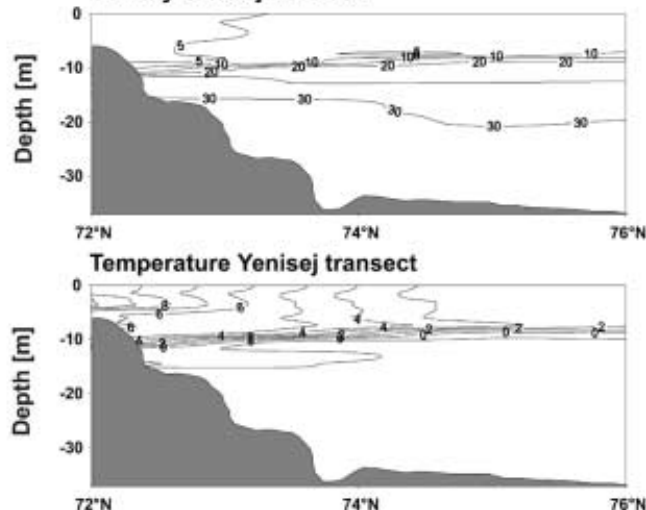
$6^{\circ} \mathrm{C}$ in the $\mathrm{Ob}$ to $4{ }^{\circ} \mathrm{C}$ further north (Table 1 ). In the south, a pronounced halocline was established at around $10 \mathrm{~m}$ depth, which on the $\mathrm{Ob}$ transect flattened out through progressive mixing towards the northern parts. The halocline was deeper on the Yenisej transect than on the $\mathrm{Ob}$ transect, suggesting a higher discharge of fresh water in the former. Below the halocline, a tongue of high-saline water reached far into the estuaries. In the $\mathrm{Ob}$ at the southernmost sta. 10, salinities $>25$ were registered near the bottom; in the Yenisej, salinities were around 15 . The deeper layer had temperatures between $0^{\circ}$ and $-1^{\circ} \mathrm{C}$ except at the shallow stations $(30,32)$ in the Yenisej, where temperatures up to $5.8^{\circ} \mathrm{C}$ were measured. In depressions, cold winter water of $-1.5^{\circ} \mathrm{C}$ and a salinity of 32 were found (Churun and Ivanov 1998).

\section{Zooplankton composition}

A total of 58 species were identified, with 25 species of Copepoda (20 Calanoida, 1 Harpacticoida and 4 Cyclopoida), 6 gelatinous species, 3 Amphipoda, 2 Cladocera, 2 Rotatoria, 2 Pteropoda, 2 Chaetognatha, 2 Appendicularia and 1 Mysidacea and Euphausiacea. Meroplanktic larvae of Cirripedia, Polychaeta, Bivalvia, Gastropoda, Echinodermata, Bryozoa and nauplii of copepods, Euphausiacea and Ostracoda were counted but not determined to species level (Table 2). Of all animals collected, $84.9 \%$ belonged to the Copepoda, with $74.3 \%$ Calanoida, and $10.6 \%$ Harpacticoida and Cyclopoida. Within the Calanoida, Drepanopus bungei $(58.7 \%)$ was by far the most abundant species and dominated the zooplankton communities at all stations (Table 3). Other species showed much lower abundances, such as C. glacialis (1.4\%), Microcalanus pygmaeus $(1.4 \%), P$. acuspes $(3.5 \%)$, P. major $(3.5 \%)$ and within the Cyclopoida, Cyclops strenuus $(3 \%)$ and O. similis $(6.2 \%)$. The next largest group was that of the copepod nauplii (13.6\%). All other groups contributed with $<1 \%$ to the total (Table 2). Dominant copepodite stages within the Calanoida were CIII to CV, which made up $72 \%$. This stage composition was characteristic of most families. Early copepodites were mostly found in D. bungei and Pseudocalanus spp., while Limnocalanus macrurus was dominated by adults.

\section{Regional distribution}

An overall mean of $1,960 \pm 412$ individuals $\mathrm{m}^{-3}$ was calculated for all stations. However, there was a strong regional variability both in abundance and species number between the two river systems and along a south to north gradient (Tables 1, 3). In the Ob estuary, the highest abundances (sts. 10, 47, 48) and the highest number of species (sts. 30, 48, 49) were found. Along a transect from the inner $\mathrm{Ob}$ estuary to the north (Table 1), species numbers first increased from 18 species at st. 10 to 30 species at sts. 48 and 49 , and then slowly decreased to 26 species at the northernmost st. 52. In the Yenisej river, both abundance and species number were much lower than in $\mathrm{Ob}$ Bay, but increased towards the north to high abundances at sts. 21, 24 and 42 to the northeast of the Taymyr Peninsula (Table 1). The distribution of dominant species is presented in Table 3. It shows clearly that high zooplankton abundances were mostly due to mass occurrences of the copepod $D$. bungei, which was found at all stations.

Vertical distribution showed strong differences between the two depth layers sampled (Table 1). Generally, the lower layers showed 2-4 times higher abundances and slightly higher species numbers than the upper layers. Several species were more frequent in the lower layers, such as Calanus glacialis, Jaschnovia tolli, M. pygmaeus, P. major and Oncaea borealis. Only at the innermost st. 10 in the $\mathrm{Ob}$ were more specimens present in the surface layer. There, D. bungei dominated the bulk. This species was generally less abundant in the marine waters below the halocline

Cluster analysis resulted in five distinctive groups identified as "Yenisej River", "Ob River", "Estuarine", "Brackish" and "Marine" (Fig. 4a). The species that mainly characterised the clusters were Diaptomus spp. and Cyclops strenuus in the "Yenisej River", Cyclops strenuus in the "Ob River", the combination of Eurytemora sp. and Oithona similis in the "Estuarine", and P. major, Oithona similis, Pseudocalanus spp., Calanus glacialis and juvenile Asterioida in the "Brackish". The "Marine" stations were mainly characterised by M. Xpygmaeus, P. major, Oithona similis, P. acuspes, Calanus glacialis and Oncaea borealis. Copepod nauplii occurred in all groups except "Brackish". The regional distribution of the clusters (Fig. 5a) closely reflects the surface pattern of salinity and temperature (Fig. 2).

Community analysis using MDS based on species assemblage and abundance showed a strong gradient from the inner estuaries to the outer more marine areas, but the distinction between brackish and marine stations was less clear (Fig. 4b). Differences between the zooplankton assemblage of the "Yenisej estuary" and the "Ob estuary" showed up in both the cluster analysis and MDS. On the latter, the stations are aligned in a south to north direction, which probably reflects the salinity gradient. The large statistical distance between the neighbouring sts. $30 / 27$ and 10/47 indicates pronounced hydrographic fronts between these stations, but only minor differences further to the north along the transect. Differences between the two rivers probably reflect their different salinity regimes (Fig. 2).

\section{9}

\section{Hydrography}

In 1999, the station positions were slightly different. In the west, the working area was limited to $74^{\circ} \mathrm{E}$, and in the north to $74.5^{\circ} \mathrm{N}$. The depth range of the 24 stations 
Table 2. Species list and relative abundance $(\%$ of total abundance per station) during the expeditions "Boris Petrov" 1997 and 1999. Species with $\geq 1 \%$ rel. abundance in bold type

\begin{tabular}{|c|c|c|c|}
\hline Group & & 1997 & 1999 \\
\hline \multirow[t]{22}{*}{ Calanoida } & Acartia longiremis & 0.1 & - \\
\hline & Calanus finmarchicus & 0.1 & 0.1 \\
\hline & Calanus glacialis & 1.4 & 2.3 \\
\hline & Calanus hyperboreus & $<0.1$ & $<0.1$ \\
\hline & Centropages hamatus & $<0.1$ & - \\
\hline & Diaptomus gracilis & $<0.1$ & - \\
\hline & Diaptomus sp. & 0.4 & 0.9 \\
\hline & Drepanopus bungei & $\mathbf{5 8 . 7}$ & 44.7 \\
\hline & Eurytemora sp. & 0.2 & $<0.1$ \\
\hline & Heterocope appendiculata & - & $<0.1$ \\
\hline & Jaschnovia c.f. brevis & 0.3 & 0.8 \\
\hline & Jaschnovia tolli & 0.5 & 1.7 \\
\hline & Limnocalanus macrurus & 0.5 & 10.6 \\
\hline & Metridia longa & 0.1 & $<0.1$ \\
\hline & Microcalanus pygmaeus & 1.4 & 0.6 \\
\hline & Neoscolecithrix farrani & - & $<0.1$ \\
\hline & Pareuchaeta glacialis & $<0.1$ & $<0.1$ \\
\hline & Pareuchaeta norvegica & $<0.1$ & - \\
\hline & Pseudocalanus acuspes & 3.5 & 3.5 \\
\hline & Pseudocalanus major & 3.5 & 12.6 \\
\hline & Pseudocalanus spp. & 3.6 & - \\
\hline & Temora longicornis & $<0.1$ & - \\
\hline Harpacticoida & Harpacticoida spp. & $<0.1$ & 0.2 \\
\hline \multirow[t]{3}{*}{ Cyclopoida } & Cyclops strenuus & 3.0 & 4.3 \\
\hline & Microsetella norvegica & $<0.1$ & $<0.1$ \\
\hline & Oithona similis & 6.2 & 7.3 \\
\hline Poecilostomatoi & Oncaea borealis & 0.9 & 0.4 \\
\hline \multirow[t]{3}{*}{ Cladocera } & Bosmina longirostis & - & $<0.1$ \\
\hline & Bosmina sp. & 0.1 & 0.4 \\
\hline & Daphnia sp. & $<0.1$ & 0.1 \\
\hline \multirow{2}{*}{ Nauplii } & Nauplii Copepoda & 13.6 & 7.7 \\
\hline & Nauplii Euphausiacea & $<0.1$ & - \\
\hline Cirripedia & Cypris larvea & $<0.1$ & - \\
\hline \multirow[t]{4}{*}{ Amphipoda } & Acanthostepheia malmgreni & $<0.1$ & - \\
\hline & Hyperia galba & $<0.1$ & $<0.1$ \\
\hline & Gammarida gen. sp. & $<0.1$ & 0.1 \\
\hline & Themisto libellula & - & $<0.1$ \\
\hline Ostracoda & Ostracoda spp. & $<0.1$ & $<0.1$ \\
\hline Mysidacea & Mysis oculata & $<0.1$ & 0.2 \\
\hline Euphausiacea & Thysanoessa rashii & $<0.1$ & - \\
\hline \multirow[t]{5}{*}{ Hydromedusa } & Aeginopsis laurentii & $<0.1$ & $<0.1$ \\
\hline & Eumedusa birulai & $<0.1$ & $<0.1$ \\
\hline & Euphysa flammea & $<0.1$ & $<0.1$ \\
\hline & Halitholus yoldia-arcticae & $<0.1$ & $<0.1$ \\
\hline & Obelia sp. & $<0.1$ & - \\
\hline \multirow{2}{*}{ Ctenophora } & Ctenophora spp. & $<0.1$ & - \\
\hline & Beroe cucumis & - & $<0.1$ \\
\hline Foraminifera & Foraminifera spp. & - & $<0.1$ \\
\hline \multirow[t]{2}{*}{ Tintinnida } & Tintinnopsis beroidea & - & $<0.1$ \\
\hline & Tintinnopsis fimbriata & - & $<0.1$ \\
\hline \multirow[t]{4}{*}{ Rotatoria } & Brachionus guadridentata & - & 0.1 \\
\hline & Keratella cochlearis & $<0.1$ & 0.1 \\
\hline & Keratella guadrata & - & 0.6 \\
\hline & Sychaeta sp. & $<0.1$ & $<0.1$ \\
\hline Nematoda & Nematoda spp. & - & 0.1 \\
\hline \multirow[t]{3}{*}{ Polychaeta } & Polychaeta larvae & 0.5 & 0.1 \\
\hline & Polychaeta pelagobia & - & $<0.1$ \\
\hline & Polychaeta spp. juv & $<0.1$ & 0.1 \\
\hline \multirow{2}{*}{ Pteropoda } & Limacina sp. & 0.1 & $<0.1$ \\
\hline & Clione limacina & 0.2 & $<0.1$ \\
\hline Bivalvia & Bivalvia larvae & 0.1 & - \\
\hline Gastropoda & Gastropoda larvae & $<0.1$ & - \\
\hline Chaetognatha & Eukrohnia hamata & $<0.1$ & - \\
\hline & Sagitta elegans & 0.2 & 0.2 \\
\hline Appendicularia & Fritillaria borealis & 0.1 & $<0.1$ \\
\hline & Oikopleura vanhoeffeni & 0.1 & 0.1 \\
\hline Echinodermata & Asteroida/Ophiuroida spp. juv. & 0.3 & - \\
\hline & Echinodermata sp. juv. & 0.1 & $<0.1$ \\
\hline & Plutei spp. & 0.1 & - \\
\hline Bryozoa & Bryozoa larvae & $<0.1$ & - \\
\hline Number of species & & $\Sigma=58$ & $\Sigma=51$ \\
\hline
\end{tabular}


Table 3. Abundance (individuals $\mathrm{m}^{-3}$ ) of dominant zooplankton species during the expeditions "Boris Petrov" 1997 and 1999. Stations are sorted according to clusters (Fig. 4a, c)

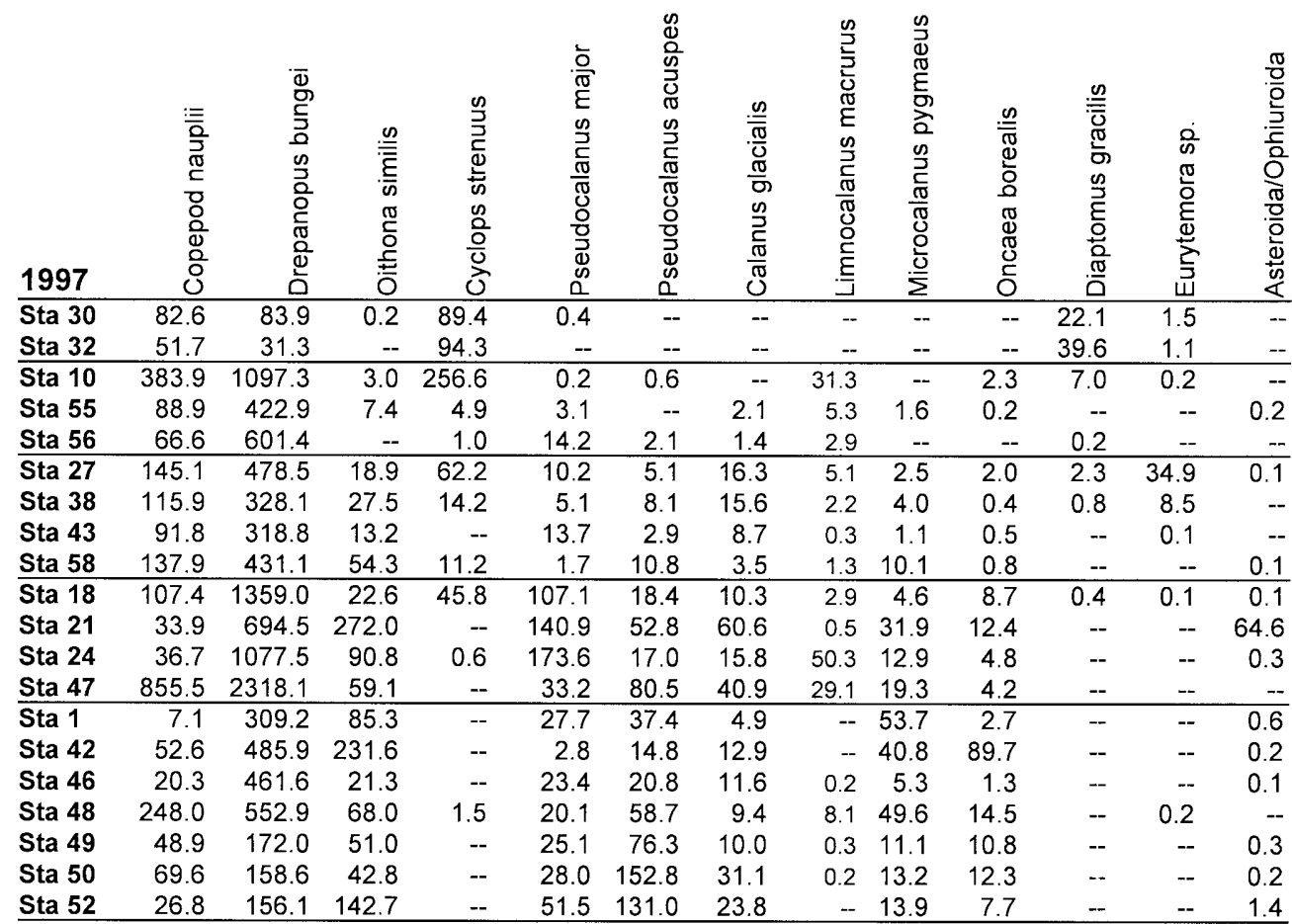

visited in 1999 varied from a maximum of $38 \mathrm{~m}$ (st. 39) in the central part of the Kara Sea to 5 m (st. 6) in the inner estuary of the Yenisej river. Details of the hydrographic situation are described by Stephansev and Shmelkov (2000) and Amon and Köhler (2000). Both surface salinity and temperature in the study area were generally lower in 1999. The distribution pattern of surface salinity was similar to 1997 (Fig. 3); differences in the distribution pattern of surface salinity in the southwestern part were at least partly due to the shift of several stations on the $\mathrm{Ob}$ transect to the east in 1999. The 1999 data showed a strong east to west gradient 
Fig. 4. 1997: Cluster dendrogram (a), MDS plot (b). 1999: Cluster dendrogram (c), MDS plot (d)
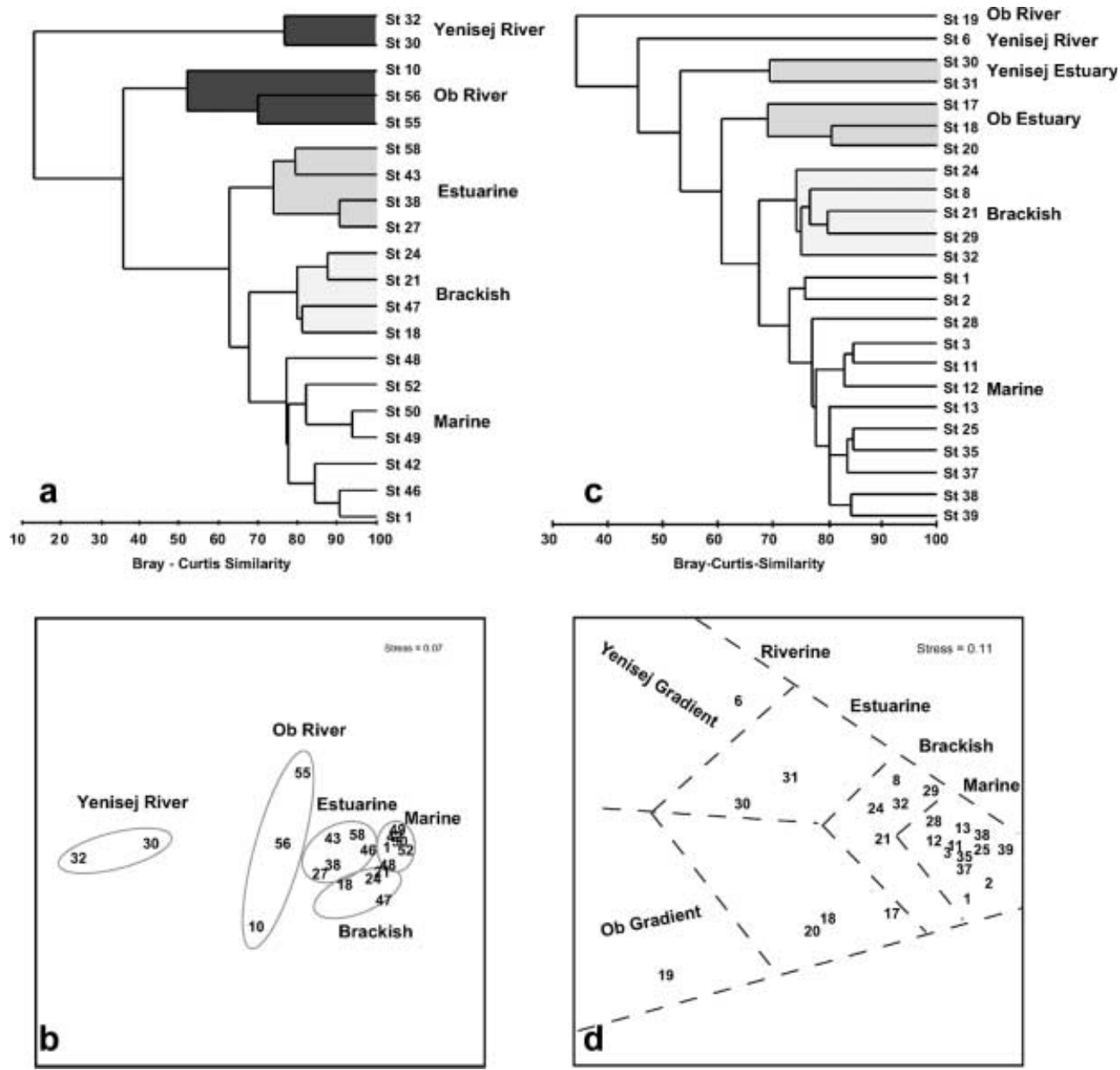

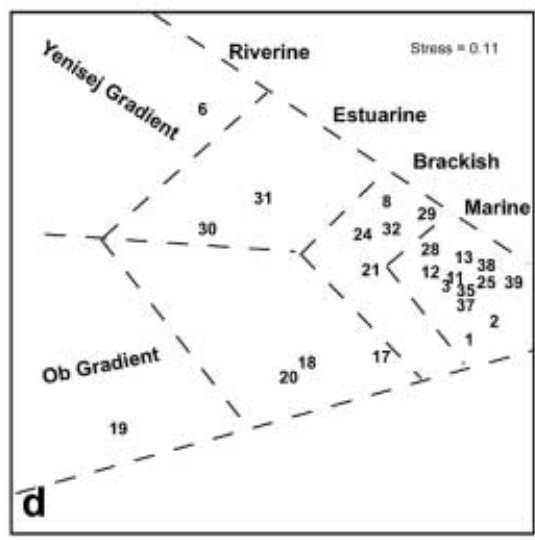

there. Both rivers showed differences in their surface salinity (Fig. 3). While the inner parts of Ob Bay showed a minimum salinity value of about 2 , which slowly increased to about 10 towards the outer parts, in the southernmost station in the Yenisej river, surface salinity was at 2.7 slightly higher. Surface temperature ranged between 3.5 and $7^{\circ} \mathrm{C}$ in both rivers and their estuaries. At the northernmost stations, where the influence of the cooler marine water masses became more prominent, the surface temperature decreased to $2.9^{\circ} \mathrm{C}$. As in 1997, the bottom temperatures showed constant values between 0 and $-1.9^{\circ} \mathrm{C}$, but the bottom salinity was at 33 slightly higher than 2 years before. The halocline was deepest at the southernmost stations with $13 \mathrm{~m}$ and flattened to $10 \mathrm{~m}$ towards the north, where the marine water masses became more important. As in 1997, high-saline waters reached far into the rivers (Fig. 2c, d) below the halocline.

\section{Zooplankton composition}

In 1999, only 51 species were identified (Table 2). Again, the largest share belonged to the Copepoda with 21 species (16 Calanoida, 1 Harpacticoida, 4 Cyclopoida). In addition, three Cladocera species, three Amphipoda, one Mysidacea, four Hydromedusa, one Ctenophora, two Tintinnida, four Rotatoria, two Pteropoda, one Chaetognatha and two Appendicularia species were found. Furthermore, Ostracoda, as well as larvae and juveniles of Polychaeta, Echinodermata and Nematoda, were observed, which were not determined to species level. Some of the meroplanktic groups such as Bivalvia, Gastropoda, Cirripedia and Bryozoa larvae were missing this year. Although copepod nauplii were present, no nauplii of euphausiids were found in the samples. In addition, several species common in 1997, such as the calanoids Acartia longiremis, Centropages hamatus, Diaptomus gracilis, P. minutus, Temora longicornis, the amphipod Acanthostepheia malmgreni, the hydromedusa Aglantha digitale, Obelia sp. and Ctenophora spp., were absent. In contrast, other species such as the calanoids Heterocopte appendicularia and Neoscolethrix farrani, the amphipod Themisto libellula, the ctenophore Beroe curcuma, pelagic Foraminifera and Tintinnida, the Rotatoria Brachionus quadridentata and Keratella quadrata, the Nematoda and juvenile Polychaeta pelagobia, were new in the samples (Table 2).

Copepods again dominated abundance with $89.9 \%$ (Table 2). Twelve percent of the total was represented by Cyclopoida, $0.2 \%$ by Harpacticoida and $77.7 \%$ by $\mathrm{Ca}-$ lanoida. The most common calanoid copepods were 
Fig. 5. Regional distribution of 1997 clusters from Fig. 4a (a); regional distribution of 1999 clusters from Fig. 4c (b)
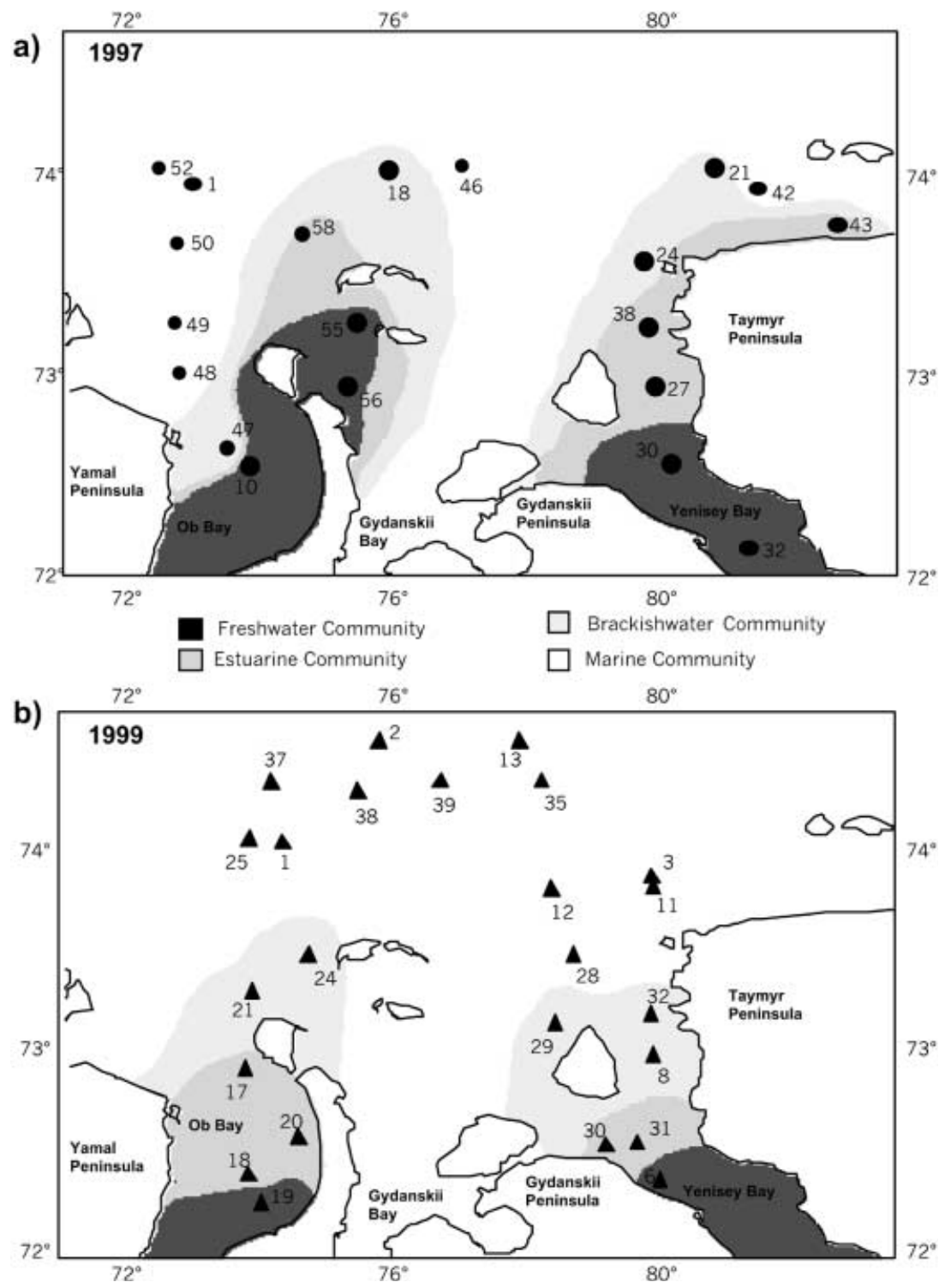

Drepanopus bungei (44.7\%), followed by Pseudocalanus major $(12.6 \%)$ and L. macrurus $(10.6 \%)$. Other quite common species of this group were Calanus glacialis $(2.3 \%), \quad J$. tolli $(1.7 \%)$ and Pseudocalanus acuspes $(3.5 \%)$. Copepoda nauplii $(7.7 \%)$ were also fairly common. Within the Cyclopoida, Oithona similis $(7.3 \%)$ and Cyclops strenuus $(4.3 \%)$ were again the most important. In contrast to 1997, many copepod species were represented by all copepodite stages. Only L. macrurus was dominated by adults; earlier copepodites were only found at the two southernmost stations in Ob Bay.

\section{Regional distribution}

An overall mean of $1,955 \pm 232$ individuals $\mathrm{m}^{-3}$ was calculated for all stations, which is very similar to 1997. One of the biggest differences was the much higher density of animals in the upper water layers in 1999 $\left(1,084 \pm 142\right.$ individuals $\left.\mathrm{m}^{-3}\right)$ than in $1997(638 \pm 132$ individuals $\mathrm{m}^{-3}$ ). In contrast, the lower layers showed fewer individuals in $1999\left(1,101 \pm 210\right.$ individuals $\left.\mathrm{m}^{-3}\right)$ than in $1997\left(1,652 \pm 313\right.$ individuals $\left.\mathrm{m}^{-3}\right)$. In 1999, the highest densities occurred in the central parts (Table 1) while the numbers of specimens in the inner $\mathrm{Ob}$ and Yenisej estuaries were only moderate. The highest concentration was found at st. $29\left(4,000\right.$ individuals $\left.\mathrm{m}^{-3}\right)$ in the southeastern Kara Sea. The species richness showed a slight tendency to higher values further outside. Both along the Yenisej and at the inner stations of the middle transect, 15 species were caught. This number increased to 25 species at the outer marine parts. Along the $\mathrm{Ob}$ transect (Table 1), a sharp increase from 15 species (st. 19) to 29 (st. 18) was observed within a short distance. As on the other transect, the number of species finally decreased to 27 at the northernmost st. 37.

Most species were found in both depth layers sampled; exceptions were Oncaea borealis and M. pygmaeus, 
which were mainly restricted to the deeper layer. In all other species there was no clear preference for water depth.

The characteristic changes in species number and abundance along the transect described above are clearly expressed in the community analysis. Cluster analysis produced six groups, named "Ob River", "Yenisej River", "Yenisej Estuary", "Ob Estuary", "Brackish" and "Marine" (Fig. 4c). The MDS plot (Fig. 4d) shows the gradual change from different community types in both rivers that converge to a homogenous marine community with increasing marine conditions. The most important species for the cluster "Ob River" were J. brevis, Cyclops strenuus and $K$. quadrata, for the "Yenisej River" Diaptomus spp. and Cyclops strenuus, for the "Ob Estuary" Pseudocalanus acuspes, Pseudocalanus major, Cyclops strenuus, Oithona similis and K. quadrata. The copepods Diaptomus spp. and Cyclops strenuus were the characteristic species combination of the "Yenisej Estuary". The presence of Pseudocalanus major and J. tolli mainly structured the group "Brackish", while Oithona similis, Calanus glacialis, Pseudocalanus acuspes, Pseudocalanus major and M. pygmaeus contributed to the "Marine" cluster. The regional distribution of the clusters (Fig. 5b) was very similar to 1997 (Fig. 5a), given the differing station locations between these years.

\section{Discussion}

Our species inventory of the southern Kara Sea agrees well with earlier observations in this area (Timofeev 1989; Vinogradov et al. 1995a), which reported Pseudocalanus major as one of the most abundant species in the marine layers beside Calanus finmarchicus s.l., while $D$. bungei and L. macrurus were the typical species for the freshwater layers. During this study, D. bungei dominated the bulk and was present at almost all stations. Similarly, L. macrurus was quite common in the lower layers within the estuaries where the salinity did not exceed 28 . This species was originally described as a relict freshwater species (Sars 1903), but it seems to have a wide range of osmotic tolerance. It is reported from many cold and deep freshwater lakes of the northern hemisphere, but is also quite common in the coastal waters of Canada, Siberia and Alaska (Roff and Carter 1972; Bowman and Long 1973; Løvik 1979; Vanderploeg et al. 1998). Single populations are also found in the Baltic and Caspian Seas (Holmquist 1970).

The zooplankton communities found here match with more than $75 \%$ of all species described by Kosobokova et al. (1998) for the shallow parts of the Laptev Sea Shelf, although there salinity was much higher. Only such freshwater species as Diaptomus spp. and the cladocerans Daphnia sp. and Bosmina sp., as well as some of the harpacticoid and amphipod species, were missing in the Laptev Sea. The great importance of crustaceans and especially the calanoid copepods seems to be typical for Arctic seas (Timofeev 1989; Kosobokova et al. 1998; Kosobokova and Hirche 2000).

For many species, all life stages were found, suggesting successful breeding within the estuaries. This was also observed by Vinogradov et al. (1995a). In contrast, stenohaline marine and freshwater species may not hatch in the estuaries and may be advected by the estuarine circulation. It is noteworthy that life-history stages of the abundant copepod L. macrurus were almost exclusively adult. Evidently this species had already completed its life cycle, as Sars (1903) described it as reproducing during the late winter and early spring.

Community analysis demonstrated clearly the effect of hydrographic conditions on zooplankton distribution, which agreed with water-mass distribution and the general circulation patterns. Zooplankton assemblages showed a distinct change from a low number of freshwater species at the innermost stations of the estuaries to a maximum number in the mixing region, where brackish water overlay marine water masses and hence inhabitants of both systems were present. Finally, the northern regions with the strongest marine characteristics were inhabited by slightly less species. Surprisingly, despite large salinity differences, there was no effect of the two different depth layers on cluster analysis. We assume that our sampling method did not effectively separate the communities inhabiting the two depth layers. As the halocline is a transition zone, the nets may always have sampled parts of the other layer and, in addition, some of the euryhaline species may be able to migrate through the halocline.

Both cluster analysis and MDS showed differences between the communities of $\mathrm{Ob}$ and Yenisej in both years studied, pointing to general differences between the plankton communities. Several factors may account for this:

- While the $\mathrm{Ob}$ is a typical river of the plains, flowing through the taiga forest and tundra zones, the Yenisej drains the upper and middle mountain areas of the Ural (Telang et al. 1991). It may, therefore, transport more mineral components and less organic material, thus creating a different food environment. Nöthig and Kattner (1999) reported the highest silicate concentrations during the 1997 cruise for the mouth of the Yenisej river, reflecting the river's rocky origin (Sukhoruk and Tokarev 2000). This is also supported by samples taken during the expedition where high contents of lithogenic clastics were observed (Unger et al. 2000).

- In contrast to the $\mathrm{Ob}$, the Yenisej has a rather narrow but deep opening into the Kara Sea, which may result in different mixing processes. This in turn may affect, directly or via phytoplankton development, the structure of zooplankton communities.

- Different nutrient regimes and mixing dynamics may lead to different spring bloom dynamics. Thus, in 1997, highest chlorophyll concentrations were measured in 
the Yenisej estuary (Nöthig and Kattner 1999). In 1999, a strong phytoplankton bloom was observed in the $\mathrm{Ob}$ estuary, but not in the Yenisej estuary (Larionov and Kodina 2000).

The regional distribution patterns of the clusters, especially in 1997 (Fig. 5a, b), mirror the spreading of fresh water from rivers in a northeastern direction, along the eastern shorelines according to the general circulation patterns of the Yamal current in the southern Kara Sea (Budgen et al. 1982; Burenkov and Vasilkov 1995; Pavlov and Pfirman 1995). This causes the hydrographic and biological gradients, at least in the southern Kara Sea, to run in a southeast-northwest direction rather than south to north. Recent modelling studies modified the current view of the circulation in the Kara Sea, and showed a strong seasonality of the circulation patterns in the southern region (Harms et al. 2000). They suggest that the circulation patterns and hence the zooplankton distribution described here are typical only for the autumn/winter period. A seasonal change of the currents, together with the interannual variability of the freshwater supply by the rivers, should strongly affect the zooplankton distribution and should be considered in future studies. Of special interest is the fate of the brackish-water fauna, which is spread over a large area in summer. The models also predict seasonal variability of the trajectories of particles exported by the two rivers.

Interannual comparison of the two cruises is difficult due to different timing and different station position, especially at the southernmost riverine stations, where the freshwater and the brackish-water communities are separated by steep fronts (e.g. in 1997, sts. 10 and 47 in Fig. 5a). The cruise in 1997, which started 3 weeks later than in 1999, met higher water temperatures, and higher salinities. Nevertheless, the general distribution patterns of the zooplankton communities were very similar, but there were marked differences in species composition and abundance. Fewer species were found in 1999, mainly due to the absence of most meroplanktic and several copepod species (Table 2). Evidently, the pelagic larvae were not yet released. However, Fomin (1989) reported that, for example, Polychaeta and Bivalvia are commonly found in the Kara Sea throughout the year.

A striking difference between the 2 years was the much higher abundance in the upper water layers in 1999 (Table 1). The difference in abundance is mainly due to the enormous increase of L. macrurus and Pseudocalanus major (Table 3) in 1999. The total number of L. macrurus increased by a factor of 21 . Also, its distribution was more widespread. While it occupied $(>1 \%$ of individuals present at each station) only $50 \%$ of all stations in 1997 , it was present at $96 \%$ in 1999 . Its spatial distribution patterns covaried with those of the copepod $D$. bungei. The abundance of Pseudocalanus major increased by a factor of 5, but in the opposite way to L. macrurus. While its main centre of distribution was at the northeastern edge in the study area in 1997, it had shifted south into the Yenisej estuary in 1999. In contrast, the number of calanoid nauplii was more prominent in 1997. Similarly to the meroplanktic species, the copepods may not have spawned before the 1999 cruise.

These differences in zooplankton composition and abundance between 2 years point to large variability of the pelagic system of the southern Kara Sea. The factors controlling mass occurrences of one or the other species are not understood, partly because there is little knowledge of the life cycles of these species.

Acknowledgements We thank the captain and crew of the RV "Akademik Boris Petrov". Victor Khorshev and Alexandr Latko helped onboard during sampling. Also, thanks go to Leonid Stephantsev, Boris Shmelkov and the Vernadsky Institute for providing the CTD data. This work was supported by BMBF 03G0539A1, Project Siberian River Run-Off (SIRRO).

\section{References}

Amon R, Köhler H (2000) Distribution of surface-water salinity. In: Stein R, Stephanets O (eds) Scientific cruise report of the joint Russian-German Kara Sea expedition of RV "Akademik Boris Petrov" in 1999. Ber Polarforsch 360:20-21

Blanchet D, Wilkman G, Golovin N, De Franco S (1995) Ice expedition in the Kara Sea in 1993. Proceedings of the second international conference on the development of the Russian Arctic offshore (RAO-95). Nauka, St. Petersburg

Bowman TE, Long A (1973) Relict populations of Drepanopus bugei and Limnocalanus macrurus grimaldii (Copepoda: Calanoida) from Ellesmere Island, N.W.T. Arctic 21:173-180

Budgen GL, Hargrave BT, Sinclair MM, Tang CL, Theriault J-C, Yeats PA (1982) Freshwater runoff effects in the marine environment: the Gulf of St. Lawrence example. Can Tech Rep Fish Aquat Sci 1078:1-89

Burenkov VI, Vasilkov AP (1995) The influence of runoff from land on the distribution of hydrologic characteristics of the Kara Sea. Oceanology 34:591-599

Cherkis NZ, Fleming HS, Max MD, Vogt PR, Czarnecki MF, Kristoffersen V, Midthassel A, Rokoengen K (1991) Bathymetry of the Barents and Kara Seas. Geological Society of America, Boulder, Colo

Churun V, Ivanov B (1998) Investigations of the hydrophysical structure in the mixing zone between fresh and saline waters in the $\mathrm{Ob}$ and Yenisei estuaries. In: Matthiessen J, Stephanets $\mathrm{O}$ (eds) Scientific Cruise Report of the Kara Sea Expedition of RV "Akademik Boris Petrov" in 1997. Ber Polarforsch 266:11-18

Clarke KR (1993) Non-parametric multivariate analyses of change in community structure. Aust J Ecol 18:117-143

Clarke KR, Warwick RM (1994) Change in marine communities: an approach to statistical analysis and interpretation. Plymouth Marine Laboratory. Bourne Press

Fomin OK (1989) Some characteristic structures of the zooplankton (in Russian). In: Matishov GG (ed) The ecology and bioresources of the Kara Sea. Murmansk Marine Biological Institute, Akademia Nauk SSSR, Apatiti, pp 65-85

Gordeev VV, Martin JM, Sodorov IS, Sidorova MV (1996) A reassessment of the eurasian river input of water, sediment, major elements and nutrients to the Arctic Ocean. Am J Sci 296: 664-691

Harms IH, Karcher MJ, Dethleff D (2000) Modelling Siberian river runoff - implications for contaminant transport. J Mar Syst 27:95-115

Hirche H-J, Hagen W, Mumm N, Richter C (1994) The northeast water polynya, Greenland Sea. 3. Meso- and macrozooplankton distribution and production of dominant herbivorous copepods during spring. Polar Biol 14:491-503

Holmquist C (1970) The genus Limnocalanus (Crustacea, Copepoda). Z Zool Syst Evolutionsforsch 8:273-296 
Kosobokova KN, Hirche H-J (2000) Zooplankton distribution across the Lomonosov Ridge, Arctic Ocean: species inventory, biomass and vertical structure. Deep Sea Res 47:2029-2060

Kosobokova KN, Hanssen H, Hirche H-J, Knickmeier K (1998) Composition and distribution of zooplankton in the Laptev Sea and adjacent Nansen Basin during summer, 1993. Polar Biol 19:63-76

Larionov VV, Kodina LA (2000) Phytoplankton of the Ob and Yenisei transects. In: Stein R, Stepanets O (eds) Scientific Cruise Report of the Joint Russian-German Kara Sea Expedition of RV "Akademik Boris Petrov" in 1999. Ber Polarforsch $360: 36$

Lisitsyn AP (1995) The marginal filter of the ocean. Oceanology 34:671-682

Lisitsyn AP, Vinogradov ME (1995) International high-latitude expedition in the Kara Sea (the 49th cruise of the R/V Dimitry Mendeleev). Oceanology 34:583-590

Lisitsyn AP, Shevchenko VP, Vinogradov ME, Serverina OV, Vivilova VV, Mitskevich IN (1995) Particle fluxes in the Kara Sea and $\mathrm{Ob}$ and Yenisey estuaries. Oceanology 34:683-693

Løset S, Shkhinek K, Gudmestad OT, Strass P, Michalenko E, Frederking R, Kärnä T (1999) Comparison of the physical environment of some Arctic seas. Cold Regions Sci Technol 29:201-214

Løvik JE (1979) Zooplankton in Randsfjorden. Fauna 32:18-28

Makkaveev PN (1995) Dissolved inorganic carbon in the Kara Sea and in the mouths of the $\mathrm{Ob}$ and Yenisey Rivers. Oceanology 34:606-610

Mironov E, Spinchkin VA, Egorov A (1994) Season variability and their variations in the region of mastering of the Barents and Kara Sea offshore. Proceedings of the first international conference on development of the Russian Arctic offshore (RAO93). Nauka, St. Petersburg

Mitskevich IN, Namsaraev BB (1995) The distribution of bacterioplankton in the Kara Sea in September 1993. Oceanology 34:641-645

Nöthig E-M, Kattner G (1999) Distribution of phytoplankton biomass and nutrient concentrations. In: Matthiessen J, Stephanets OV, Stein R, Fütterer D, Galimov EM (eds) The Kara Sea expedition of RV "Akademik Boris Petrov" 1997: First results of a joint Russian-German pilot study. Ber Polarforsch 300:37-44

Pavlov VK, Pfirman SL (1995) Hydrographic structure and variability of the Kara Sea: implications for pollutant distribution. Deep Sea Res 42:1369-1390

Roff JC, Carter JCH (1972) Life cycle and seasonal abundance of the copepod Limnocalanus macrurus Sars in a high arctic lake. Limnol Oceanogr 17:363-370

Roman MR (1984) Utilisation of detritus by the copepod Acartia tonsa. Limnol Oceanogr 29:949-959
Sars GO (1903) An account of the Crustacea of Norway. 4 Copepoda Calanoida. Universitetsforlaget, Bergen

Stephansev L, Shmelkov B (2000) Brief characteristics and results from measurements of hydrophysical structures of waters in the estuaries of $\mathrm{Ob}$ and Yenisei. In: Stein R, Stephanets $\mathrm{O}$ (eds) Scientific Cruise Report of the Joint Russian-German Kara Sea Expedition of RV "Akademik Boris Petrov" in 1999. Ber Polarforsch 360:8-19

Sukhoruk VI, Tokarev VG (2000) Sea water hydrochemistry and nutrients. In: Stein R, Stepanets O (eds) Scientific cruise report of the joint Russian-German Kara Sea expedition of RV "Akademik Boris Petrov" in 1999. Ber Polarforsch 360:22-27

Tackx MLM, Zhu L, De Coster W, Billones R, Daro MH (1995) Measuring selectivity of feeding by estuarine copepods using image analysis combined with microscopic and Coulter counting. ICES Mar Sci Symp 52:3-4

Telang SA, Pocklington R, Naidu AS, Romankevich EA, Gitelson II, Gladyshev MI (1991) Carbon and mineral transport in major North American, Russian Arctic and Siberian rivers: the St. Lawrence, the Mackenzie, the Arctic Alaskan rivers, the Arctic Basin rivers in the Soviet Union and the Yenisei. In: Degens ET, Kempe S, Richey JE (eds) Biogeochemistry of major world rivers. SCOPE 42:74-104

Timofeev SF (1989) The pelagic architecture of the Kara Sea (in Russian). In: Matishov GG (ed) The ecology and bioresources of the Kara Sea. Murmansk Marine Biological Institute, Akademia Nauk SSSR, Apatiti, pp 86-93

Unger D, Neumann K, Fetzer I (2000) Sediment trap investigations in the Kara Sea. In: Stein R, Stepanets O (eds) Scientific Cruise Report of the Joint Russian-German Kara Sea Expedition of RV "Akademik Boris Petrov" in 1999. Ber Polarforsch 360:2835

Vanderploeg HA, Cavaletto JF, Liebig JR, Gardner WS (1998) Limnocalanus macrurus (Copepoda: Calanoida) retains a marine arctic lipid and life cycle strategy in Lake Michigan. J Plankton Res 20:1581-1597

Verdernikov VI, Demidov AB, Sudbin AI (1995) Primary production and chlorophyll in the Kara Sea in September 1993. Oceanology 34:630-640

Vinogradov ME, Shuskina EA, Lebedeva LP, Gagarin VI (1995a) Mesoplankton in the East Kara Sea and the $\mathrm{Ob}$ and Yenisey River estuaries. Oceanology 34:646-652

Vinogradov ME, Nikolaeva GG, Khoroshilov VS (1995b) The mesoplankton of the West Kara Sea and the Baidara Bay. Oceanology 34:653-660

Volkov V, Kosheleva GJ, Smolyanitsky V, Vinje T (1997) Natural conditions of the Kara and Barents Seas. Proceedings of the Russian-Norwegian Workshop-95. Norsk Polarinstitut, Oslo 